\title{
Curcumin Requires Tumor Necrosis Factor $\alpha$ Signaling to Alleviate Cognitive Impairment Elicited by Lipopolysaccharide
}

\author{
E.M. Kawamoto ${ }^{\text {a C. Scavone }}{ }^{\text {b M.P. Mattson }}{ }^{\text {a }}$ S. Camandola ${ }^{\text {a }}$ \\ a Laboratory of Neurosciences, National Institute on Aging, Intramural Research Program, Baltimore, Md., USA; \\ ${ }^{\text {b}}$ Department of Pharmacology, Institute of Biomedical Sciences, University of São Paulo, São Paulo, Brazil
}

\section{Key Words}

Curcumin • Tumor necrosis factor $\alpha \cdot$ Cognition •

Inflammation $\cdot$ Lipopolysaccharide

\begin{abstract}
A decline in cognitive ability is a typical feature of the normal aging process, and of neurodegenerative disorders such as Alzheimer's, Parkinson's and Huntington's diseases. Although their etiologies differ, all of these disorders involve local activation of innate immune pathways and associated inflammatory cytokines. However, clinical trials of anti-inflammatory agents in neurodegenerative disorders have been disappointing, and it is therefore necessary to better understand the complex roles of the inflammatory process in neurological dysfunction. The dietary phytochemical curcumin can exert anti-inflammatory, antioxidant and neuroprotective actions. Here we provide evidence that curcumin ameliorates cognitive deficits associated with activation of the innate immune response by mechanisms requiring functional tumor necrosis factor $\alpha$ receptor 2 (TNFR2) signaling. In vivo, the ability of curcumin to counteract hippocampusdependent spatial memory deficits, to stimulate neuroprotective mechanisms such as upregulation of BDNF, to decrease glutaminase levels, and to modulate N-methyl-D-aspartate receptor levels was absent in mice lacking functional TNFRs. Curcumin treatment protected cultured neurons
\end{abstract}

\section{KARGER}

E-Mail karger@karger.ch www.karger.com/nsg (c) 2012 S. Karger AG, Basel
1424-862X/13/0212-0075 $\$ 38.00 / 0 \quad$ Karger
This is an Open Access article licensed under the terms of This is an Open Access article licensed under the terms of Derivs 3.0 License (www.karger.com/OA-license), applicaDerivs 3.0 License (www.karger.com/OA-license), applica-
ble to the online version of the article only. Distribution for non-commercial purposes only. against glutamate-induced excitotoxicity by a mechanism requiring TNFR2 activation. Our results suggest the possibility that therapeutic approaches against cognitive decline designed to selectively enhance TNFR2 signaling are likely to be more beneficial than the use of anti-inflammatory drugs per se.

Copyright $\odot 2012$ S. Karger AG, Basel

\section{Introduction}

The activation of innate immune cells in the central nervous system (CNS), principally microglia, and subsequently the generation of cytokines [e.g. tumor necrosis factor $\alpha$ (TNF- $\alpha$ ), interleukin (IL)-1 $\beta$, and IL-6] and reactive oxygen species are major components of the neuroinflammatory response to injury, infection and neurodegenerative disease [1]. Increasing evidence suggests that local inflammatory processes contribute to neuronal dysfunction and associated neurological symptoms in neurodegenerative disorders, stroke, traumatic brain injury and HIV dementia [2-4]. However, the assumption that pro-inflammatory molecules exert only detrimental effects on CNS function has been challenged by evidence that cytokines play roles in cognition and synaptic plasticity [5]. For example, it was recently reported that IL-1 $\beta$ is essential for physiological regulation of memory [6]. Ge-

Simonetta Camandola

Laboratory of Neurosciences, National Institute on Aging Intramural Research Program

251 Bayview Blvd, Baltimore, MD 21224 (USA)

Tel. +1 410558 8617, E-Mail camandolasi@ mail.nih.gov 
netic ablation or blockage of the IL-1 $1 \beta$ receptor impairs long-term potentiation and hippocampus-dependent memory $[7,8]$, while $1 \mathrm{~L}-1 \beta$ administration improves avoidance memory and contextual fear conditioning [7]. Mice deficient in IL- 6 display impaired hippocampus-dependent and -independent memory [9]. TNF- $\alpha$, tumor necrosis factor $\alpha$ receptor 1 (TNFR1) and TNFR2 knockout mice all exhibit learning and memory retention impairment, with a more pronounced phenotype in mice devoid of TNF- $\alpha$ signaling $[5,10]$. These findings indicate that the role played by glia and neuroinflammatory molecules is far more complex than was previously appreciated.

Although neuroinflammation is associated with neuropathologies and cognitive decline, clinical trials using anti-inflammatory drugs have not been encouraging. For example, although epidemiological data suggested that nonsteroidal anti-inflammatory drugs may reduce the risk for Alzheimer's disease (AD) [11-13], large randomized, placebo-controlled clinical trials using both steroidal and nonsteroidal drugs yielded negative results [14] and in a few cases accelerated progression of the disease $[15,16]$.

The therapeutic use of natural compounds in Western medicine has increased as a result of controlled studies substantiating beneficial effects of some such natural products in experimental disease models $[17,18]$. Curcumin, the principal polyphenol of the spice turmeric (Curcuma longa), exhibits anti-inflammatory, antioxidant, antitumor, metal-chelating, neuroprotective and antiamyloidogenic properties [19]. Because of its pleiotropic actions [20] and potential ability to preserve cognitive performance in the elderly [21], we assessed the effect of curcumin on cognitive impairment elicited by activation of toll-like receptor 4 (TLR4), a prominent component of the innate immune system, by bacterial lipopolysaccharide (LPS). TLR4 plays important roles in the response of CNS cells to infection and tissue injury [22], and is also implicated in local inflammatory processes in neurodegenerative diseases [23]. Here we show that curcumin alleviates LPS-induced cognitive impairment by a mechanism requiring TNF- $\alpha$ signaling via TNFR2.

\section{Animals and Methods}

\section{Animals and Treatments}

Adult 12- to 14-week-old male TNFR1 and TNFR2 double knockout (DKO) and control background (C57BL/6J) (WT) mice were kept under a 12-hour light/12-hour dark cycle and allowed free access to food and water. All treatments were administered between 8:00 and 11:00 AM. Each animal received $50 \mathrm{mg} / \mathrm{kg}$ of curcumin (Sigma-Aldrich, St. Louis, Mo., USA) intraperitoneally for 4 days followed by a single $250 \mu \mathrm{g} / \mathrm{kg}$ LPS (O111:B4) (SigmaAldrich) dose $2 \mathrm{~h}$ after the last curcumin administration. The LPS and curcumin doses used in this study have been reported to induce memory impairment and neuroprotection, respectively, in murine experimental models [24, 25]. Based on the experimental end point, mice were euthanized either $4 \mathrm{~h}$ or 7 days after LPS administration. This research was performed according to guidelines in the NIH Guide for the Care and Use of Laboratory Animals.

\section{Morris Water Maze}

The test was performed as previously described [26]. Mice were trained in a circular tank containing water $\left(22 \pm 1^{\circ} \mathrm{C}\right)$ rendered opaque by the addition of nontoxic paint (Palmer Paints Products Inc., Mich., USA). Spatial visual clues were provided in the form of differently shaped objects on the walls of each quadrant. An escape platform $(10 \times 10 \mathrm{~cm})$ was submerged approximately $1 \mathrm{~cm}$ below the surface of the water, $10 \mathrm{~cm}$ from the edge of the tank at a position designated as quadrant 3 (target quadrant). The swimming path length was monitored with a Videomex tracking system, and data were collected using Videomex Water Maze Software (Columbus Instruments, Ohio, USA). The training period consisted of four 60 -second trials per day, with each mouse released into the water at a different quadrant for each trial. Learning retention (spatial memory) was measured in two probe trials at 4 and $24 \mathrm{~h}$ after the last training session. For both probe trials, the platform was removed and mice were allowed to swim freely in the tank for $60 \mathrm{~s}$.

\section{Open Field Test}

Mice were placed in the center of an open field apparatus (40 $\times 40 \mathrm{~cm}$ ), and ambulation scores (the number of squares crossed) and the number of rearings and peepings were measured during a 15-min period over 3 days after LPS treatment.

\section{Rotarod}

Motor skills were tested using the ENV-577M Rotarod system (Med Associates, Georgia, Vt., USA). The time spent on the rod and the number of falls from the rotating rod was measured for each animal during 300-second trials (the speed of rod rotation was increased progressively from 3 to $30 \mathrm{rpm}$ during the $300-\mathrm{sec}$ ond period).

\section{Fear Conditioning}

Mice were habituated to the testing room for 5 consecutive days. During the training session, mice were placed in a contextual conditioning chamber (model MED-VFC-NIR-M; Med Associates) and allowed to explore for $2 \mathrm{~min}$. The mice were subjected to 3 sessions of a 30 -second neutral discrete stimulus (conditioned stimulus, audio tone $6 \mathrm{kHz}, 70 \mathrm{~dB}$ ), followed by $2 \mathrm{~s}$ of a motivationally significant stimulus (unconditioned stimulus; foot shock, $0.5 \mathrm{~mA}$ ). Each session of conditioned and unconditioned stimulus pairings was separated by $30 \mathrm{~s}$. On the following day during the contextual fear session, mice were returned in the same conditioning cage for $5 \mathrm{~min}$ without any stimulus. In the cued session, mice were placed in the chamber in a different context and allowed to explore for $5 \mathrm{~min}$ before being subjected to 5 audio tones over a 5 -min period. The percentage of time freezing was recorded in both sessions and used as an index of either contextual or cued memory. 
Primary Cultures and Experimental Treatments

Primary hippocampal and cortical neuronal cells were prepared as described [27]. For all in vitro experiments cells were pretreated for $24 \mathrm{~h}$ with vehicle dimethyl sulfoxide or $10 \mu \mathrm{M}$ curcumin and then exposed to $200 \mu \mathrm{M}$ glutamate. Recombinant TNFR2 (1 $\mu \mathrm{g} / \mathrm{ml})$ (A.G. Scientific, San Diego, Calif., USA) and $1 \mu \mathrm{g} / \mathrm{ml}$ TNFR2 neutralizing antibody (Santa Cruz Biotechnology, Calif., USA) or control IgG were added at $24 \mathrm{~h}$ and $30 \mathrm{~min}$ before glutamate challenge, respectively. Cell survival was assessed $24 \mathrm{~h}$ after addition of glutamate using a CellTiter 96 AQueous Assay System (Promega, Madison, Wisc., USA) and lactate dehydrogenase activity assay (Roche, Nutley, N.J., USA).

\section{Protein Extraction and Immunoblot Analysis}

Tissue, whole-cell extracts and nuclear fractions were prepared as described [28]. The primary antibodies used in this study were: Actin, NR1 and RelA (Sigma-Aldrich); EAAT2 and pSer897-NR1 (Cell Signaling, Danvers, Mass., USA); hnRNP C1/C2, TNFR1 and TNFR2 (Santa Cruz Biotechnology); EAAT3 (Abbiotec, San Diego, Calif., USA); GFAP (AbCam, Cambridge, Mass., USA); GluR1 (Upstate, Lake Placid, N.Y., USA); pSer845GluR1 (Millipore, Billerica, Mass., USA), and NOS (BD Transduction, Franklin Lakes, N.J., USA).

\section{RNA Extraction and Real-Time PCR}

RNA was isolated using Trizol (Invitrogen) and purified with an RNA Micro Kit (Qiagen, Valencia, Calif., USA). Real-time PCR analysis was performed with a PTC 200 Pelthier Thermo Cycler and Chromo 4 Fluorescent Detector (BioRad, Hercules, Calif., USA), and Sybr ${ }^{\circledR}$ Green PCR Master Mix according to the manufacturer's instructions (Applied Biosystems, Foster City, Calif., USA). Each reaction included $3 \mu$ lof diluted (1:4) cDNA and was performed in duplicate. The comparative Ct method was used to determine the normalized changes of the target gene relative to a calibrator reference. The genes analyzed in this study were: mBDNF (I:NM_007540, II:NM_001048139, III:NM_001048141, IV:NM_001048142), mGLS1 (NM_001081081), mHPRT (NM_ 013556), and mTrkB (NM_001025074).

\section{Statistical Analysis}

Data are expressed as mean and SEM. Statistical comparisons were performed by analysis of variance followed by post hoc Newman-Keuls test, using a Prism software package (Graphpad Software, San Diego, Calif., USA).

\section{Results}

Curcumin Ameliorates LPS-Induced Memory

Impairment

The experimental design with regard to timing of administration of curcumin and LPS is shown in figure 1a. Mice pretreated with vehicle or curcumin were administered one dose of vehicle or LPS to activate immunocompetent brain cells [24]. The effect of curcumin and LPS administration on learning and memory was evaluated using the water maze test. No differences were observed among any of the experimental groups in terms of latency to find the platform, swimming distance or swimming speed during training (online suppl. fig. 1a-c; for all online suppl. material, see www.karger.com/doi/10.1159/ 000336074), nor in the probe trial performed $4 \mathrm{~h}$ after the last training section (fig. 1b). Thus all animals were able to learn the location of the platform, and showed comparable short-term memory retention. However, LPS-treated mice displayed impaired long-term memory retention, as indicated by a significantly reduced time spent in the correct quadrant compared to control mice when tested in the probe trial $24 \mathrm{~h}$ after training (fig. 1c). These findings suggest that curcumin pretreatment ameliorates a memory consolidation deficit induced by LPS. Although the comparable performances during the learning and the first probe trials argued against any interference due to LPS-induced motor function impairment, we further evaluated the motor skills of the mice using a rotarod apparatus. LPS-treated mice displayed motor problems during the first 2 days after treatment, with a reduced time spent on the rotating rod (fig. 1d) and an increased number of falls (fig. 1e). Their performance became indistinguishable from the other groups by $72 \mathrm{~h}$ after LPS administration (fig. 1d). Notably, curcumin pretreatment prevented the LPS-induced deficits in rotarod performance (fig. 1d, e), as well as the anxiety-like behaviors exhibited by the LPS-treated mice in the open field test (fig. 1f, g). Similarly to what was observed in the Morris water maze, all animals equally learned to associate a tone with an electric shock in the fear conditioning paradigm (online suppl. fig. 1d), and performed identically during the amygdala-dependent cued test (online suppl. table 1). However, in the hippocampus-dependent contextual fear paradigm the LPS-treated mice froze less than the control group, an effect again ameliorated by curcumin pretreatment (fig. 1h). Collectively, our results suggest that LPS causes cognitive impairment, specifically a deficit in long-term memory retention, which can be ameliorated by a short-term curcumin pretreatment.

\section{Curcumin Reduces Peripheral and CNS Inflammation}

Long-term curcumin administration has been shown to exert anti-inflammatory [29] and neuroprotective effects in several experimental models [30]. Because we opted for a short-term pretreatment, we examined the extent of inflammation by measuring pro-inflammatory markers in the serum and hippocampus at early $(4 \mathrm{~h})$ and late (7 days) time points after drug administration. LPS caused a significant increase of TNF- $\alpha$ and IL-1 $\beta$ levels which was prevented by curcumin pretreatment administered 


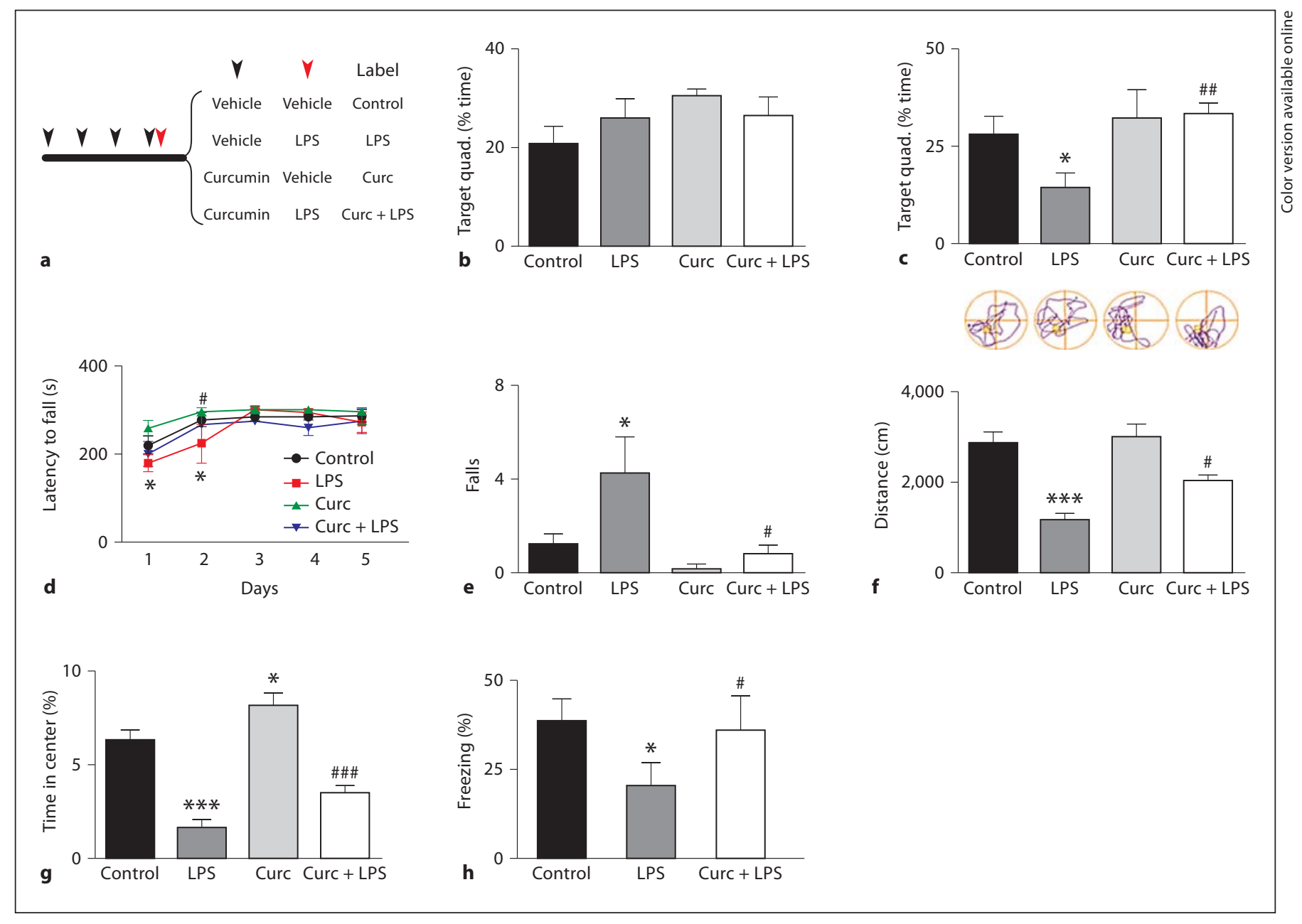

Fig. 1. Curcumin ameliorates LPS-induced memory impairment. a Experimental design. Mice were treated with either vehicle or curcumin for 4 consecutive days (black arrow), followed by a single injection of vehicle or LPS (red arrow). Mice were trained in the Morris water maze for 5 consecutive days. The time spent in the target quadrant is expressed as percentage of the total time for the probe trial performed $4 \mathrm{~h} \mathrm{(b)}$ and $24 \mathrm{~h}$ (c) after training $(\mathrm{n}=$ 10). Beginning $24 \mathrm{~h}$ after LPS injection, mice were tested daily for motor performance on a rotarod, the latency to fall (d) and the total number of falls during the testing period (e) are shown ( $\mathrm{n}=$ 10). Results of analysis of behavior in the open field test showing the total distance traveled (f) and time spent in the center of the open field $(\mathbf{g})(\mathrm{n}=10)$. $\mathbf{h}$ Percentage of time spent freezing during the contextual phase of the fear conditioning paradigm $(n=4-5)$. ${ }^{*} \mathrm{p}<0.05$ versus control; ${ }^{* * *} \mathrm{p}<0.001$ versus control; ${ }^{*} \mathrm{p}<0.05$ versus LPS; ${ }^{\#} \mathrm{p}<0.01$ versus LPS; ${ }^{\# \#} \mathrm{p}<0.001$ versus LPS. For colors, see online version. either systemically (fig. 2a, b) or in the brain (fig. 2c, d). In the hippocampus, the protein levels of nitric oxide synthase (NOS), glial fibrillary acidic protein (GFAP), and the nuclear translocation of RelA (NF- $\kappa$ B activation) were elevated in response to LPS, and curcumin prevented the latter inflammatory cell responses (fig. 2f). One week after LPS exposure, the levels of TNF- $\alpha$, IL-1 $\beta$ and NOS returned to basal levels (online suppl. table 2), while markers of NF- $\kappa \mathrm{B}$ and glial cell activation remained significantly elevated only in the LPS-treated group (fig. 2e).

\section{Curcumin Requires TNF- $\alpha$ Signaling to Prevent the} Adverse Effects of LPS on Cognitive Function

Cytokines can influence cognition, and TNF- $\alpha$ is considered a key cytokine in the pro-inflammatory process [31]. To investigate the role played by TNF- $\alpha$ signaling in the LPS-induced cognitive impairment and curcumin protection, we performed behavioral testing using a TNFR1 and TNFR2 DKO mouse model which is completely devoid of TNF- $\alpha$ signaling [32]. The effects of LPS on rotarod performance in $\mathrm{DKO}$ mice were comparable 

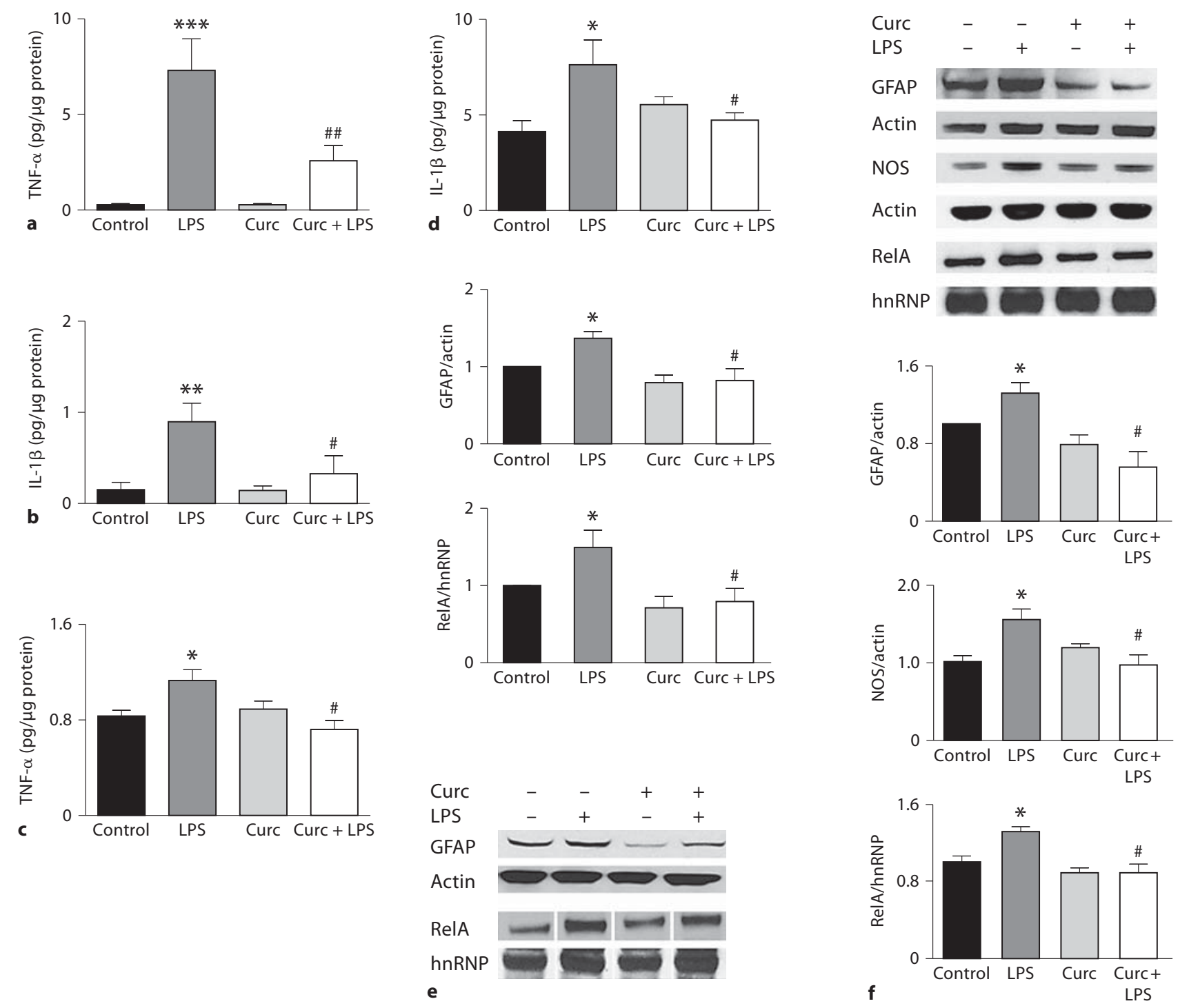

Fig. 2. Effects of LPS and curcumin on pro-inflammatory markers. Levels of TNF- $\alpha$ and IL-1 $\beta$ were measured $4 \mathrm{~h}$ after treatment in serum $(\mathbf{a}, \mathbf{b})$ and in hippocampal extracts $(\mathbf{c}, \mathbf{d})$ by ELISA $(\mathrm{n}=$ 10). Representative immunoblots and densitometric analysis of multiple blots showing relative levels of GFAP, NOS, and nuclear RelA in hippocampi of mice killed either $4 \mathrm{~h}(\mathbf{f})$ or 7 days (e) after treatment. Levels of $\beta$-actin and hnRNP were used as internal loading controls for whole-cell extracts and purity of the nuclear fraction, respectively $(\mathrm{n}=10) .{ }^{*} \mathrm{p}<0.05$ versus control; ${ }^{* *} \mathrm{p}<0.01$ versus control; ${ }^{* *} \mathrm{p}<0.001$ versus control; ${ }^{*} \mathrm{p}<0.05$ versus LPS; \#\# $\mathrm{p}<0.01$ versus LPS. to those observed in WT mice with decreased latency time to fall (fig. 3a) and increased number of falls (data not shown) during the first 2 days after treatment, and full recovery by the third day. However, in DKO mice, curcumin failed to prevent LPS-induced sickness (fig. 3a). As recently reported [33], in the open field, DKO mice were overall less anxious than WT mice, spending more time in the center of the field (WT, C $=6.26 \pm 0.61 \%$; $\mathrm{DKO}, \mathrm{C}=15.8 \pm 1.56 \%$ ). LPS treatment diminished the distance traveled regardless of the type of pretreatment (fig. 3b). During the nonspatial visible platform variant of the water maze, DKO mice spent most of the time floating in the pool, and swam toward the visible platform only when prompted. This lack of motivation agrees with 


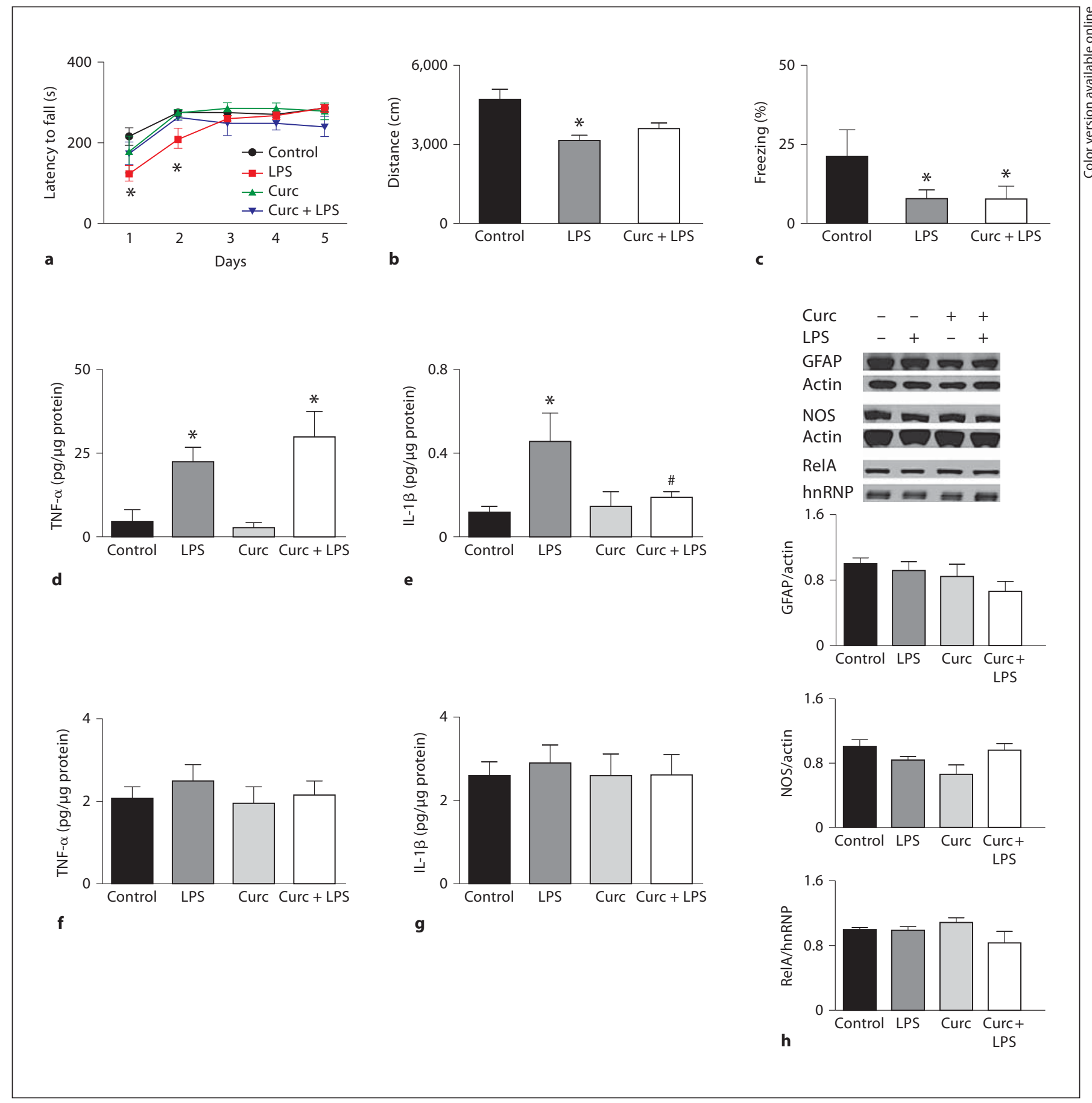

Fig. 3. Amelioration of LPS-induced behavioral impairment by curcumin requires TNF receptors. DKO mice were tested on various behavioral test following treatment with curcumin and/or LPS. a Latency to fall off the rotarod over a 5-day testing period. b Distance traveled in the open field $48 \mathrm{~h}$ after LPS injection. c Percentage of time spent freezing in the contextual phase of the fear conditioning test $(n=4-6)$. Levels of TNF- $\alpha$ and IL-1 $\beta$ were measured $4 \mathrm{~h}$ after treatments in serum (d, e) and hippocampal extracts (f, $\mathbf{g})(\mathrm{n}=4-11)$. $\mathbf{h}$ Representative immunoblots and densitometric analysis of multiple blots showing relative levels of GFAP, NOS and nuclear RelA in the hippocampus of DKO animals treated as indicated $(n=4-6) .{ }^{*} \mathrm{p}<0.05$ versus control; ${ }^{\#} \mathrm{p}<0.05$ versus LPS. 

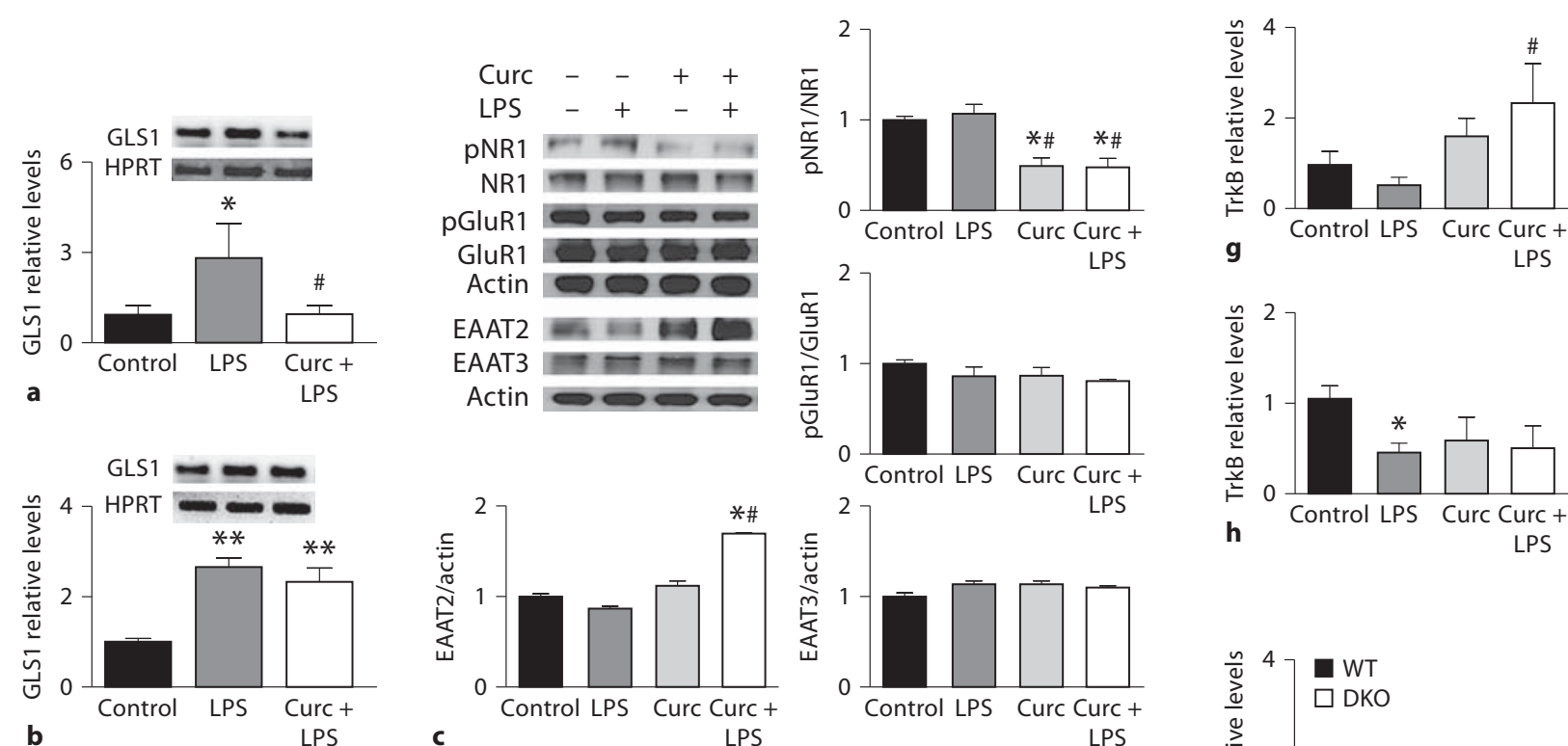

g
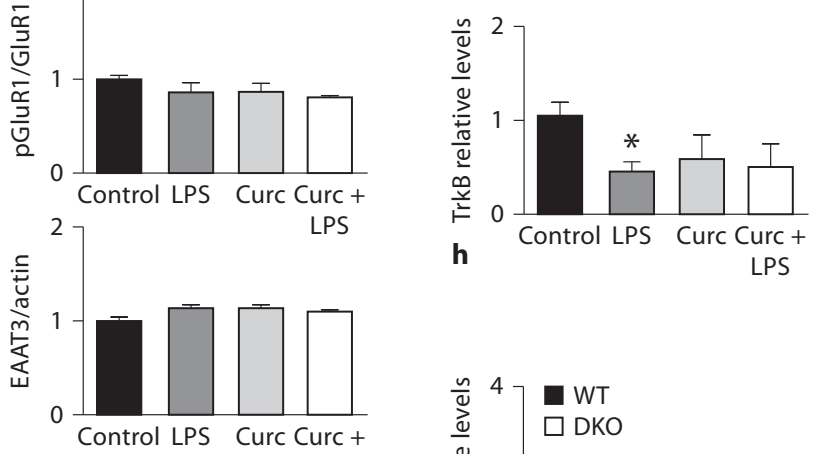

C

LPS

LPS
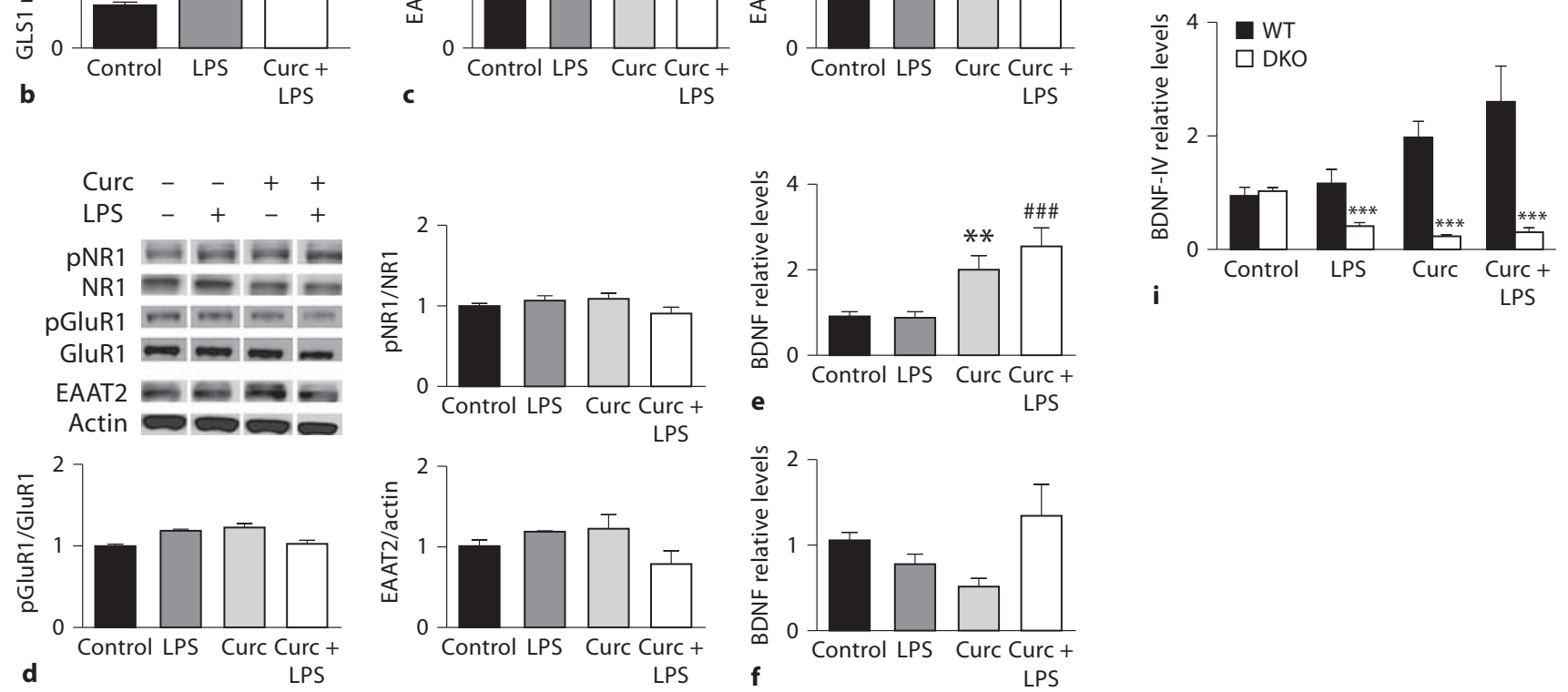

Fig. 4. Curcumin modulates glutamate and BDNF signaling. Levels of glutaminase transcript were measured by quantitative RTPCR in WT (a) and DKO (b) mice treated according to the experimental protocol and euthanized $4 \mathrm{~h}$ after LPS $(\mathrm{n}=4-5)$. Results of immunoblot analysis of glutamate transporters (EAAT2 and EAAT3) and glutamate receptor subunits (GluR1 and NR1) in the hippocampus of WT mice (c) and DKO mice $(\mathbf{d})(n=3-10)$.
Levels of mRNAs encoding BDNF and its receptor TrkB were measured by quantitative RT-PCR in samples from the hippocampus of WT mice $(\mathbf{e}, \mathbf{g})$ and DKO mice $(\mathbf{f}, \mathbf{h})(\mathrm{n}=3-6) .{ }^{*} \mathrm{p}<$ 0.05 versus control; ${ }^{* *} \mathrm{p}<0.01$ versus control; ${ }^{*} \mathrm{p}<0.05$ versus LPS; ${ }^{\# \# \# ~} \mathrm{p}<0.001$ versus LPS. i Relative levels of BDNF mRNA splice variants IV in hippocampal samples from WT and DKO mice. ${ }^{* *} \mathrm{p}<0.001$ compared to the same treatment in WT mice.
Fig. 5. Curcumin upregulates TNFR2 and prevents glutamateinduced excitotoxicity. a Relative expression of TNFR2 in hippocampi from WT mice treated with LPS. b Primary neuronal cultures were incubated with vehicle or $10 \mu \mathrm{M}$ curcumin (Curc) for $24 \mathrm{~h}$, then challenged with $200 \mu \mathrm{M}$ glutamate (Glu). Levels of TNFRs were measured $1 \mathrm{~h}$ after glutamate addition. Cell viability assessed by MTS assay (c, hippocampal and d, cortical), and lac- tate dehydrogenase (LDH) release assay (e, hippocampal and f, cortical). Survival of hippocampal neurons incubated with recombinant TNFR2 (rT2) (g) or anti-TNFR2 and IgG control (h) before glutamate challenge. All data are mean and SEM of 3-5 separate experiments. ${ }^{*} \mathrm{p}<0.05$ versus control; ${ }^{* * *} \mathrm{p}<0.001$ versus control; ${ }^{\# \#} \mathrm{p}<0.01$ versus glutamate. 

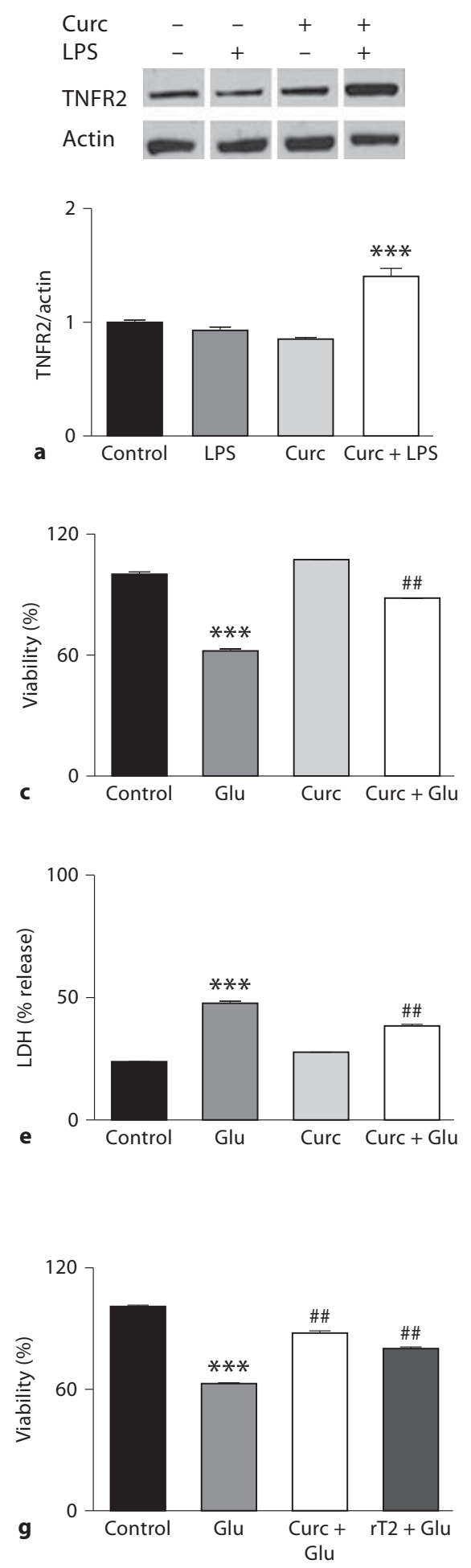

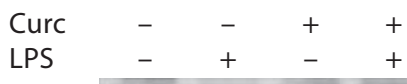

TNFR1

Actin

TNFR2

Actin
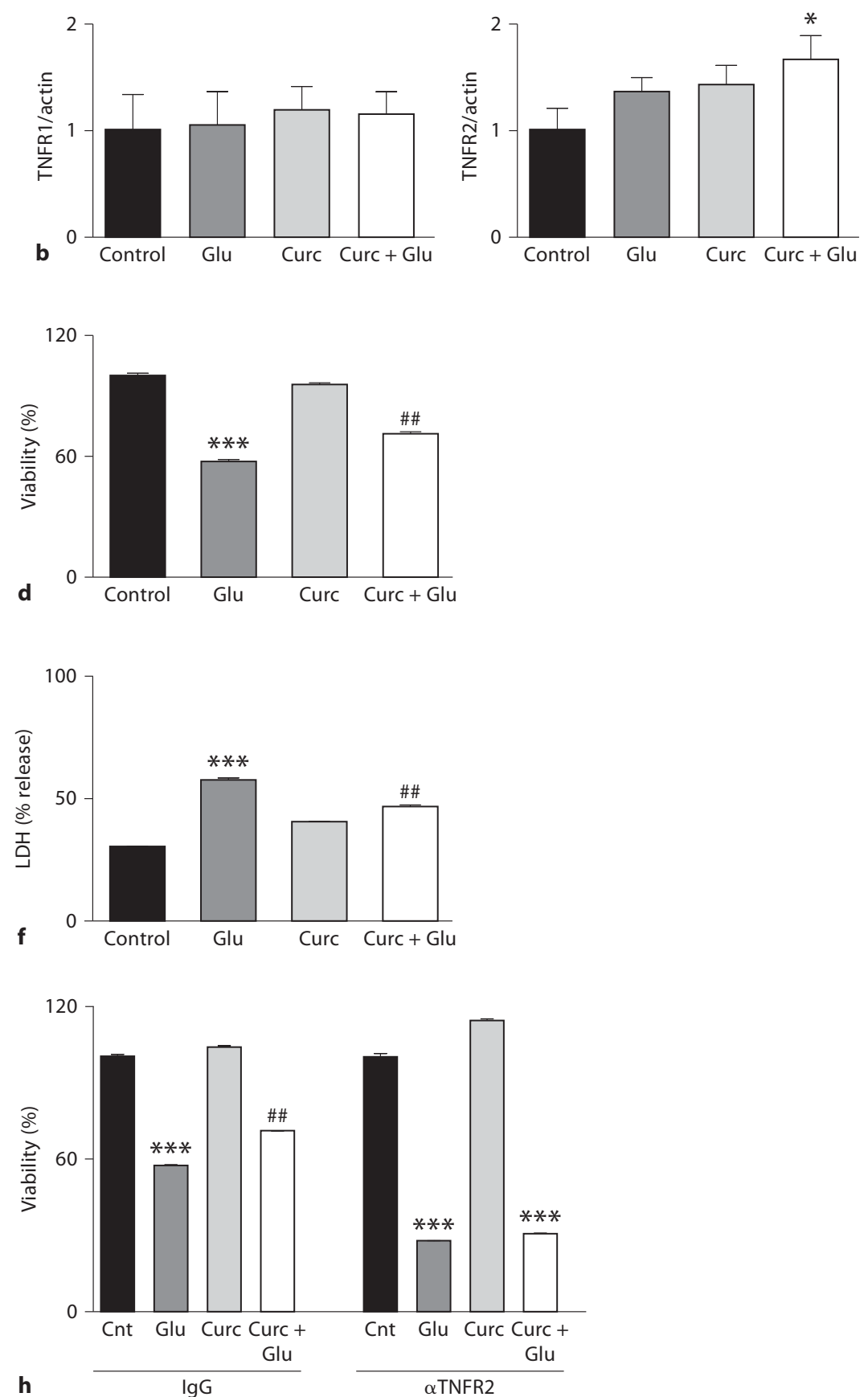
Fig. 6. Schematic of the protective mechanisms of curcumin against innate immune-induced neuronal dysfunction. a LPS causes increased glutamate production and release (red dots) which may result in overstimulation of NMDA receptors, increased intracellular $\mathrm{Ca}^{2+}$ and neuronal dysfunction. b In the presence of curcumin, LPS induces an upregulation of TNFR2 (pink). TNFR2 may exert signaling via binding to transmembrane TNF- $\alpha$ $(\operatorname{mTNF}-\alpha)$, and it can be shed resulting in decrease sTNF- $\alpha /$ TNFR1 (yellow) signaling. Changes in TNFR1/TNFR2 signaling are associated with a decrease of glutamatergic response through inhibition of glutaminase (GLS1) and NMDA receptor activity coupled with increased EAAT2 glutamate reuptake. Together with the enhancement of BDNF/TrkB (blue dots) signaling, these reactions appear to result in the preservation of neuronal functional integrity and cognitive performance. For colors, see online version.

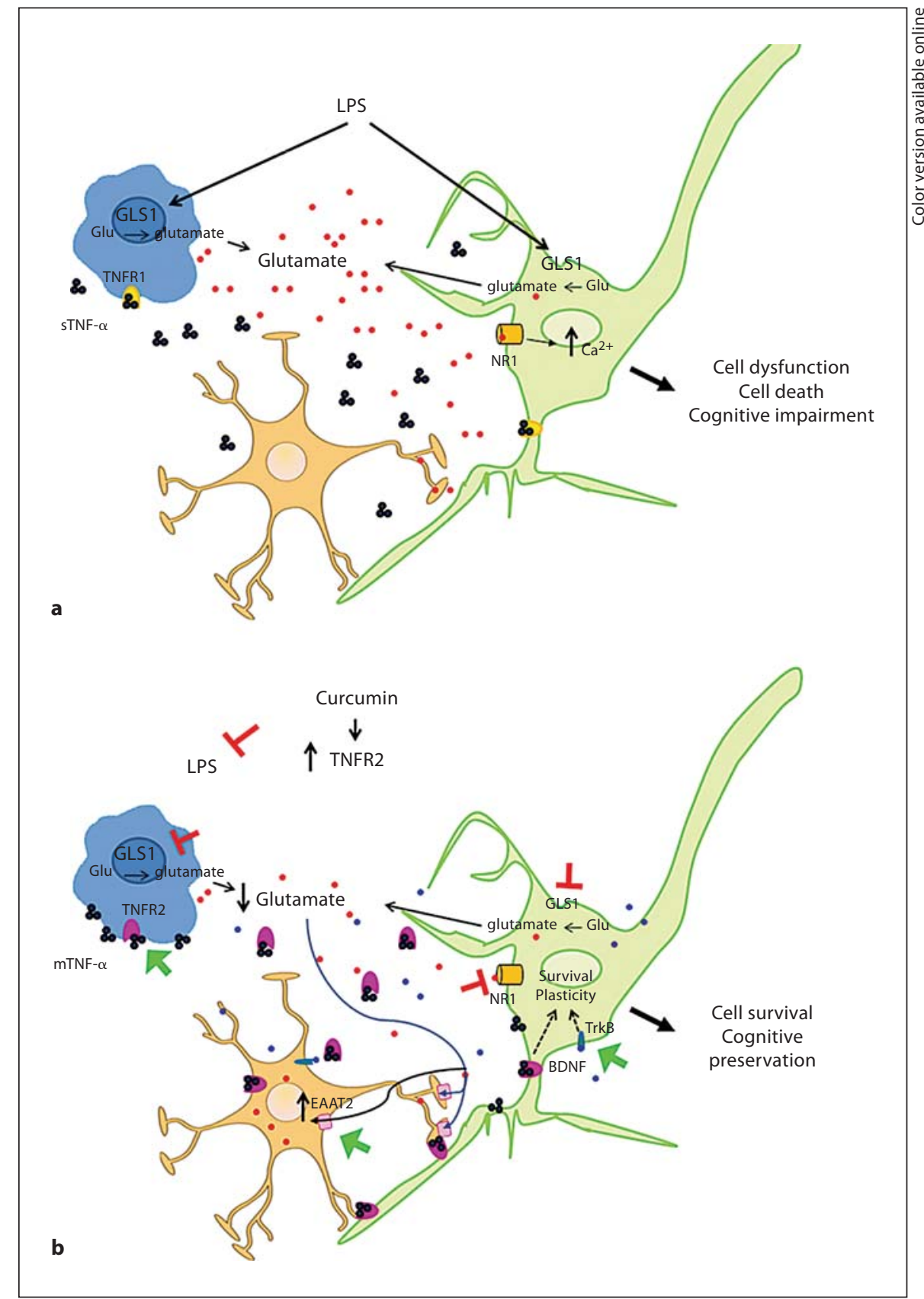

the open field observation of an anxiolytic effect of TNFR deficiency, yet prevented us from testing hippocampusdependent memory in the water maze. During the learning and cued portions of the fear conditioning test, no differences were observed between groups (online suppl. table 1), while in the contextual phase LPS caused a significant decrease in freezing which was not modified by curcumin pretreatment (fig. 3c).

Curcumin Requires TNFR to Prevent Memory Impairment
TNF- $\alpha$ Signaling Is Required for CNS LPS-Induced Inflammatory Responses but Is Dispensable for Peripheral Inflammatory Responses

The results of behavioral testing indicated that LPSinduced cognitive impairment does not require TNF- $\alpha$ signaling, while curcumin's counteractive actions do. To better understand the latter findings in the context of cellular inflammatory signaling, we evaluated peripheral 
and CNS inflammatory responses to LPS in DKO mice. As previously reported [34], we found that compared to WT mice, DKO mice have higher basal serum levels of TNF- $\alpha(\mathrm{WT}=0.28 \pm 0.07$; DKO $=4.34 \pm 3.55 \mathrm{pg} / \mu \mathrm{g}$ proteins). The serum levels of TNF- $\alpha$ and IL- $1 \beta$ were both increased by LPS administration with curcumin only preventing IL-1 $\beta$ upregulation (fig. 3d, e). These data demonstrate that in DKO mice the peripheral inflammatory response to LPS is not impaired, that curcumin antiinflammatory properties are overall unchanged, and that the decreased TNF- $\alpha$ levels found in the curcumin + LPS group among WT mice are likely not the result of reduced TNF- $\alpha$ production. In DKO mice, hippocampal levels of TNF- $\alpha$ and IL-1 $\beta$ (fig. 3f, g), as well as GFAP, NOS and nuclear RelA (fig. 3h) were not significantly affected by LPS or curcumin, indicating that contrary to the systemic response, CNS glia activation and cytokine production in response to LPS depends upon TNF- $\alpha$ signaling. Taken together with the behavioral data, our findings suggest that: (1) pro-inflammatory cytokines may not be responsible for the LPS-induced cognitive impairment; (2) the ability of curcumin to prevent the action of LPS on behavior does not depend upon its anti-inflammatory properties, and (3) curcumin's mechanism of action requires intact TNFR signaling.

\section{Curcumin Modifies Glutamate Signaling}

Glutamate signaling is essential for hippocampus-dependent spatial working memory [35]. However, high extracellular levels of glutamate and overactivation of glutamate receptors may result in sustained elevation of intracellular calcium levels, neuronal dysfunction and cell death [36]. Increased glutamate levels have been shown following LPS administration [37]. We tested how LPS and/or curcumin impacted glutamate signaling by measuring levels of glutaminase, glutamate transporters and glutamate receptors in hippocampal tissue samples from WT and DKO mice. Glutaminase (GLS1) is a mitochondrial enzyme essential for the production of glutamate present in neurons and glia [38]. GLS1 deregulation and increased glutamate production have been demonstrated in vitro for TNF $\alpha$ - and LPS-activated microglia cells [3941]. We found an LPS-induced upregulation of hippocampal GLS1 transcript levels in both mouse strains, which was prevented by curcumin only in WT mice (fig. 4a, b).

Excitatory amino acid transporters (EAATs) are responsible for the reuptake of glutamate from the synaptic cleft, thus playing a fundamental role in the termination of the glutamatergic signal and the preservation of the lo- cal integrity of excitatory synaptic transmission. We focused our analysis on EAAT2 and EAAT3. EAAT2 is almost exclusively expressed in glia, and is responsible for $90 \%$ of forebrain glutamate reuptake [42]. EAAT3 is the predominant post- and presynaptic neuronal transporter accounting for about $40 \%$ of hippocampal glutamate transport [43]. Levels of EAAT3 were unchanged, while levels of EAAT2 were significantly upregulated in WT mice that received curcumin or curcumin plus LPS (fig. 4c). In contrast, EAAT2 levels were not affected by curcumin in DKO mice (fig. 4d). EAAT2 levels were comparable in all groups and strains by day 7 (data not shown). The $\alpha$-amino-3-hydroxy-5-methylisoxazole-4propionic acid (AMPA) subunit GluR1 and the N-methyl-D-aspartate (NMDA) subunit NR1 play important roles in learning and memory processes [44]. In our experimental model, neither LPS nor curcumin significantly affected hippocampal levels of GluR1 (fig. 4c), NR1 (fig. 4c), or NR2B (control = $1.0 \pm 0.09$; LPS $=1.0 \pm 0.13$; curcumin $=0.89 \pm 0.08$; curcumin + LPS $=0.98 \pm 0.09$ ). However, in WT mice, the phosphorylation of NR1 on Ser897 was reduced by more than $50 \%$ in all mice that received curcumin (fig. 4c). Changes in phosphorylation were specific for NR1 as demonstrated by the lack of changes in GluR1 phosphorylation levels (fig. 4c), and were absent in DKO mice (fig. 4d). Similarly to EAAT2, levels of phosphorylated NR1 returned to basal values by day 7 (data not shown). The phosphorylation of Ser897 of NR1 is associated with increased receptor sensitivity to glutamate and $\mathrm{Ca}^{2+}$ currents [45]. In WT mice, curcumin pretreatment may thus result in decreased amplitude of NMDA-driven calcium influx and possibly reduced neuronal dysfunction. In DKO mice, the combined increase of glutaminase levels, with normal EAAT2 levels, and NMDA and AMPA receptor activity suggests a scenario in which release of glutamate from the presynaptic terminal during the learning process may be exaggerated and possibly deleterious.

\section{Curcumin Upregulates BDNF Signaling}

BDNF plays an important role in learning and memory, anxiety behaviors and neuroprotection [46]. In our model, we found that in WT mice, the relative levels of BDNF mRNA were upregulated in response to curcumin treatment (fig. 4e), while TrkB mRNA levels were significantly elevated only in the curcumin + LPS group (fig. 4g). In DKO mice, total levels of BDNF mRNA were similar in all groups (fig. 4f), and there was a statistically significant reduction in TrkB mRNA levels in LPStreated mice (fig. $4 \mathrm{~h}$ ). The transcriptional regulation of 
$\mathrm{BDNF}$ is quite complex and generates various transcripts from which an identical BDNF protein is produced. In the rodent brain, promoter IV accounts for the majority of the activity-dependent BDNF expression [47]. Interestingly, the most striking difference between WT and DKO mice concerned BDNF-IV, which exhibited opposite changes in expression in response to curcumin in WT mice (upregulation) and DKO mice (downregulation) (fig. 4i). Notably, BDNF-IV is also the only transcript that has been shown to be modulated by TNF- $\alpha$ [48].

\section{Curcumin Modulates TNFR2 Levels, and TNFR2}

Activation Mediates an Excitoprotective Action of

Curcumin

TNF- $\alpha$ plays complex roles in the CNS depending upon which type of receptor is engaged [49]. Activation of TNFR1 signaling pathways is generally linked to apoptosis, and in microglia it promotes glutamate release facilitating excitotoxicity [39]. On the other hand, TNF- $\alpha$ signaling via TNFR2 has been shown to be neuroprotective and neurotrophic [50-52]. Curcumin failure to protect against LPS-induced changes in DKO mice prompted us to measure levels of TNFR1 and TNFR2 in the hippocampus of WT mice. Notably, TNFR2 was significantly upregulated early on in mice receiving curcumin + LPS (fig. 5a), returning to normal levels 1 week after LPS administration. To understand how curcumininduced TNFR2 upregulation may impact neurons we moved to a cell culture system. Similarly to what was observed in vivo, TNFR1 levels were unaffected while TNFR2 levels were upregulated within $1 \mathrm{~h}$ in cells treated with curcumin and glutamate (fig. 5b). Curcumin pretreatment resulted in a significant decrease of glutamateinduced cell death in both hippocampal (fig. 5c, e) and cortical neurons (fig. $5 \mathrm{~d}, \mathrm{f}$ ). To assess the role played by TNFR2 in curcumin-induced cell protection, we used two different approaches, soluble recombinant TNFR2 (rT2; a fusion protein containing the TNFR2 extracellular domain fused to the Fc of IgG, which acts as a decoy receptor to decrease levels of soluble TNF- $\alpha$ ) and a TNFR2-neutralizing antibody. The addition of rT2 to the culture medium before glutamate exposure prevented neuronal cell death to an extent similar to curcumin (fig. 5g). On the other hand, the use of an antibody against the extracellular domain of TNFR2 exacerbated glutamate toxicity and completely nullified the protection afforded by curcumin (fig. 5h). These results are consistent with previous reports showing that TNFR2 signaling promotes neuronal survival $[49,52]$.

Curcumin Requires TNFR to Prevent

Memory Impairment

\section{Discussion}

Cognitive decline is associated with many neurodegenerative disorders, and neuroinflammation is believed to play a prominent role in the underlying synaptic dysfunction and neuronal degeneration [1]. However, in view of recent findings highlighting physiological roles for $\mathrm{cy}-$ tokines in the establishment and maintenance of learning and memory, the use of broad-spectrum anti-inflammatory therapies for chronic neurodegenerative disorders may be ineffective or even detrimental. An extensive array of health benefits attributed to curcumin has been identified in studies involving long-term supplementation (i.e., 4 weeks or longer) [53]. In contrast, there have been few studies to evaluate the prophylactic efficacy of short-term administration of curcumin. The data in the present study provide novel insight into the mechanism by which innate immune activation perturbs cognition, and how curcumin counteracts its adverse effects. Our findings suggest that: (1) cognitive impairment caused by activation of TLR4 is not mediated by TNF- $\alpha$; (2) shortterm administration of curcumin ameliorates cognitive deficits with a mechanism requiring TNFR signaling, and (3) curcumin-induced upregulation of TNFR2 is required to protect neurons from excitotoxicity.

Using LPS to elicit an immune response, we observed impairment of hippocampus-dependent memory which was efficiently prevented by a short-term supplementation with curcumin. The observed deficits were not the result of sickness behavior or learning differences amongst the experimental groups, but instead resulted from impaired memory consolidation. This result is in agreement with previous findings in rats, which the authors attributed to IL-1 $\beta$ upregulation [54]. However, our data strongly argue against an IL-1 $\beta$-dependent neuroinflammatory mechanism. In fact, curcumin was able to normalize IL-1 $\beta$ levels in both WT and DKO mice, and hippocampus glial activation and cytokine levels were unchanged in DKO mice, in which LPS caused behavioral impairment even in the presence of curcumin. These observations suggest that LPS-induced cognitive impairment is not mediated by TNF- $\alpha$ signaling, and appears to involve a signaling pathway that does not require glial cell activation nor NF- $\kappa$ B-mediated cytokine production. TLRs are expressed in astrocytes, microglia and neurons wherein their activation can affect neuronal plasticity and survival $[22,26]$. Specifically, TLR4 activation regulates neural progenitor cell self-renewal and neuronal differentiation [55], increases neuronal vulnerability to ischemia [22], regulates pain through the ex- 
pression of nociceptin, and increases excitability of dorsal root ganglion neurons [56]. Also, TLR4 activation in parenchymal cells is alone sufficient to drive a typical acute-phase response to pathogens [57].

Our results highlight a new mechanism by which curcumin protects neurons against stress. We found that in the presence of a stressor curcumin induced the expression of TNFR 2 both in vivo and in cultured neurons. This upregulation is fundamental for neuroprotection by curcumin because the ability of curcumin to ameliorate LPSinduced cognitive impairment and perturbations in the expression of glutaminase, NR1, EAAT2 and BDNF was absent in mice lacking TNFRs. Moreover, blockage of TNFR2 impaired curcumin-mediated neuroprotection, while addition of recombinant TNFR2 (which decreases soluble TNF- $\alpha$ /TNFR1 signaling) was as efficient as curcumin itself in protecting neurons against glutamate toxicity. We therefore propose that curcumin protects neurons against innate immune activation-induced cognitive impairment by triggering a shift from TNFR1- to TNFR2-mediated TNF- $\alpha$ signaling (fig. 6). Our model is supported by the recent observation that neuronal levels of TNFR2 are decreased while TNFR1 levels and its signaling are increased in the brains of AD patients compared to nondemented subjects [58]. TNFR1-mediated signaling has been shown to impair learning and memory in neurodegenerative mouse models [59]. Moreover, lack of TNFR2 exacerbates cognitive dysfunction after traumatic brain injury, while TNFR1 ablation ameliorates the cognitive deficit [60]. In addition, deletion of TNFR1 has been shown to decrease fear conditioning response [61]. Furthermore, while TNF- $\alpha$ does not seem to play a major role in acute plasticity, as shown by equivalent long-term potentiation responses in DKO and WT mice [62], it is required for homeostatic synaptic scaling and stabilization of neuronal network function [63]. TNF- $\alpha$ and BDNF have been shown to be important for maintaining synapses in a plastic state in which scaling can be expressed. TNFR1-dependent TNF- $\alpha$ signaling 'scales up' excitatory synapses by increasing cell surface AMPA receptors and reducing inhibitory $\mathrm{GABA}_{\mathrm{A}}$ receptors $[62,64]$. However, TNFR1-dependent signaling also modifies AMPA receptor stoichiometry making the channels $\mathrm{Ca}^{2+}$ permeable and so rendering neurons more susceptible to excitotoxicity [62]. On the other hand, BDNF has been shown to inhibit neuronal excitability [63], and affords neuroprotection in animal models of a range of neurodegenerative disorders [46]. We found that, in the presence of LPS, curcumin modulates factors underlying synaptic scaling (TNF- $\alpha$ and BDNF) result- ing in amelioration of cognitive deficits and enhanced neuronal resistance to excitotoxic damage.

Curcumin increased TNFR2 levels in the hippocampus of WT mice and protected against LPS-induced memory impairment, and these effects of curcumin were lost in DKO mice suggesting a fundamental role for a switch from TNFR1 to TNFR2 signaling to control neuronal network functionality in the mechanism of action of curcumin. TNF- $\alpha$ signaling is being pursued as a potential therapeutic target for neurodegenerative disorders. Among the different strategies developed to modulate TNF- $\alpha$ signaling are monomeric and dimeric (etanercept) TNFR2-Fc. Originally developed as TNF- $\alpha$ scavengers, it has become evident that their mechanism of action includes blockage of soluble TNF- $\alpha$ and induction of transmembrane TNF- $\alpha$-TNFR2-mediated signaling [65]. Etanercept has been shown to increase transmembrane TNF- $\alpha$ [66], and to trigger transmembrane TNF- $\alpha$ reverse signaling that may induce cytokine suppression and/or other cellular events. While perispinal administration of etanercept improved cognitive performance in $\mathrm{AD}$ patients in two small nonrandomized studies [67], large controlled trials to test its efficacy have not yet been completed (www.clinicaltrials.org NCT01068353). Indirect evidence substantiating the validity of TNFR2-Fc in AD comes from a recent study demonstrating a 55\% decreased incidence of $\mathrm{AD}$ in rheumatoid arthritis patients treated with etanercept versus those who received other drugs such as prednisone, sulfasalazine and rituximab [68]. While effective in several models of autoimmune disorders, a substantial drawback of the use of TNFR2-Fc is the high cost associated with the therapy.

Curcumin has been shown to ameliorate cognitive impairment in several animal models, and consumption of curry has been associated with lower risk of $\mathrm{AD}$ [69] and improved cognitive performance in elderly subjects [21]. However, large trials to determine the impact of curcumin on cognitive performance in neurodegenerative disorders have not yet been performed. The results of our study support the possible beneficial action of curcumin in treating cognitive impairment.

\section{Acknowledgements}

We thank E. Okun for advice on the behavioral testing procedures and S. Rothman for assistance in preparing the manuscript for publication. This research was supported by the Intramural Research Program of the National Institute on Aging of the National Institutes of Health, and by Program and Fundação de Amparo à Pesquisa do Estado de São Paulo-FAPESP. 


\section{References}

1 Ownby RL: Neuroinflammation and cognitive aging. Curr Psychiatry Rep 2010;12:3945.

-2 Viviani B, Bartesaghi S, Corsini E, Galli CL, Marinovich M: Cytokines role in neurodegenerative events. Toxicol Lett 2004;149:8589.

-3 Anisman H, Merali Z, Hayley S: Neurotransmitter, peptide and cytokine processes in relation to depressive disorder: comorbidity between depression and neurodegenerative disorders. Prog Neurobiol 2008;85:1-74.

4 Rojo LE, Fernández JA, Maccioni AA, Jimenez JM, Maccioni RB: Neuroinflammation: implications for the pathogenesis and molecular diagnosis of Alzheimer's disease. Arch Med Res 2008;39:1-16.

5 McAfoose J, Koerner H, Baune BT: The effects of TNF deficiency on age related cognitive performance. Psychoneuroendocrinology 2009;34:615-619.

6 Yirmiya R, Goshen I: Immune modulation or learning, memory, neuronal plasticity and neurogenesis. Brain Behav Immun 2011;25 181-213.

7 Yirmiya R, Winocur G, Goshen I: Brain interleukin-1 is involved in spatial memory and passive avoidance conditioning. Neurobiol Learn Mem 2002;78:379-389.

-8 Avital A, Goshen I, Kamsler A, Segal M, Iverfeldt K, Richter-Levin G, Yirmiya R: Impaired interleukin-1 signaling is associated with deficits in hippocampal memory processes and neural plasticity. Hippocampus 2003;13:826-834.

-9 Baier PC, May U, Scheller J, Rose-John S, Schiffelholz T: Impaired hippocampus-dependent and -independent learning in IL-6 deficient mice. Behav Brain Res 2009;200: 192-196.

10 Baune BT, Wiede F, Braun A, Golledge J, Arolt V, Koerner H: Cognitive dysfunction in mice deficient for TNF- $\alpha$ and its receptors. Am J Med Genet B Neuropsychiatr Genet 2008;147B:1056-1064.

-11 Stewart WF, Kawas C, Corrada M, Metter EJ: Risk of Alzheimer's disease and duration of NSAID use. Neurology 1997;48:626-632.

$\checkmark 12$ in t' Veld BA, Ruitenberg A, Hofman A, Launer LJ, Van Duijn CM, Stijnen T, Breteler MM, Stricker BH: Nonsteroidal antiinflammatory drugs and the risk of Alzheimer's disease. N Engl J Med 2001;345:515-521.

13 Vlad SC, Miller DR, Kowall NW, Felson DT: Protective effects of NSAIDs on the development of Alzheimer disease. Neurology 2008; 70:1672-1677.

14 Imbimbo BP, Solfrizzi V, Panza F: Are NSAIDs useful to treat Alzheimer's disease or mild cognitive impairment? Front Aging Neurosci 2010;2.pii:19.

15 Thal LJ, Ferris SH, Kirby L, Block GA, Lines CR, Yuen E, Assaid C, Nessly ML, Norman BA, Baranak CC, Reines SA, Rofecoxib Protocol 078 study group: A randomized, dou- ble-blind, study of rofecoxib in patients with mild cognitive impairment. Neuropsychopharmacology 2005;30:1204-1215.

6 ADAPT Research Group, Martin BK, Szekely C, Brandt J, Piantadosi S, Breitner JC, Craft S, Evans D, Green R, Mullan M: Cognitive function over time in the Alzheimer's Disease Anti-inflammatory Prevention Trial (ADAPT): results of a randomized, controlled trial of naproxen and celecoxib. Arch Neurol 2008;65:896-905.

- 17 Barbaste M, Berke' B, Dumas M, Soulet S, Delaunay JC, Castagnino C, Arnaudinaud V, Cheze C, Vercauteren J: Dietary antioxidants, peroxidation and cardiovascular risks. J Nutr Health Aging 2002;6:209-223.

18 Gullett NP, Ruhul Amin AR, Bayraktar S, Pezzuto JM, Shin DM, Khuri FR, Aggarwal BB, Surh YJ, Kucuk O: Cancer prevention with natural compounds. Semin Oncol 2010; 37:258-281.

19 Hatcher H, Planalp R, Cho J, Torti FM, Torti SV: Curcumin: from ancient medicine to current clinical trials. Cell Mol Life Sci 2008; 65:1631-1652.

20 Son TG, Camandola S, Mattson MP: Hormetic dietary phytochemicals. Neuromolecular Med 2008;10:236-246.

$>21 \mathrm{Ng}$ TP, Chiam PC, Lee T, Chua HC, Lim L, Kua EH: Curry consumption and cognitive function in the elderly. Am J Epidemiol 2006; 64:898-906.

22 Tang SC, Arumugam TV, Xu X, Cheng A, Mughal MR, Jo DG, Siler DA, Chigurupati S, Ouyang X, Magnus T, Camandola S, Mattson MP: Pivotal role for neuronal Toll-like receptors in ischemic brain injury and functional deficits. Proc Natl Acad Sci USA 2007; 104:13798-13803.

23 Walter S, Letiembre M, Liu Y, Heine H, Penke B, Hao W, Bode B, Manietta N, Walter J, Schulz-Schuffer W, Fassbender K: Role of the toll-like receptor 4 in neuroinflammation in Alzheimer's disease. Cell Physiol Biochem 2007;20:947-956.

24 Sparkman NL, Kohman RA, Scott VJ, Boehm GW: Bacterial endotoxin-induced behavioral alterations in two variations of the Morris water maze. Physiol Behav 2005; $86: 244-251$.

25 Jagatha B, Mythri RB, Vali S, Bharath MM: Curcumin treatment alleviates the effects of glutathione depletion in vitro and in vivo: therapeutic implications for Parkinson's disease explained via in silico studies. Free Radic Biol Med 2008;44:907-917.

26 Okun E, Griffioen K, Barak B, Roberts NJ, Castro K, Pita MA, Cheng A, Mughal MR, Wan R, Ashery U, Mattson MP: Toll-like receptor 3 inhibits memory retention and constrains adult hippocampal neurogenesis. Proc Natl Acad Sci USA 2010;107:1562515630.

27 Son TG, Camandola S, Arumugam TV, Cutler RG, Telljohann RS, Mughal MR, Moore
TA, Luo W, Yu QS, Johnson DA, Johnson JA, Greig NH, Mattson MP: Plumbagin, a novel Nrf2/ARE activator, protects against cerebral ischemia. J Neurochem 2010;112:1316-1326.

-28 Camandola S, Cutler RG, Gary DS, Milhavet O, Mattson MP: Suppression of calcium release from nositol 1,4,5-trisphosphate-sensitive stores mediates the anti-apoptotic function of nuclear factor-kappaB. J Biol Chem 2005;280:22287-22296.

29 Jurenka JS: Anti-inflammatory properties of curcumin, a major constituent of Curcuma longa: a review of preclinical and clinical research. Altern Med Rev 2009;14:141-153.

30 Ray B, Lahiri DK: Neuroinflammation in Alzheimer's disease: different molecular targets and potential therapeutic agents including curcumin. Curr Opin Pharmacol 2009;9: 434-444.

31 Clark IA: How TNF was recognized as a key mechanism of disease. Cytokine Growth Factor Rev 2007;18:335-343.

32 Bruce AJ, Boling W, Kindy MS, Peschon J, Kraemer PJ, Carpenter MK, Holtsberg FW, Mattson MP: Altered neuronal and microglial responses to excitotoxic and ischemic brain injury in mice lacking TNF receptors. Nat Med 1996;2:788-794.

-33 Patel A, Siegel A, Zalcman SS: Lack of aggression and anxiolytic-like behavior in TNF receptor (TNF-R1 and TNF-R2) deficient mice. Brain Behav Immun 2010;24:12761280.

34 Gourine AV, Leon LR, Rudolph K, Tesfaigzi J, Kluger MJ: Cytokine cascade induced by endotoxin in TNF double receptor knockout mice: evidence supporting a role for IL-10 in mediating antipyretic action of TNF. J Therm Biol 2000;25:21-27.

35 Reisel D, Bannerman DM, Schmitt WB, Deacon RM, Flint J, Borchardt T, Seeburg $\mathrm{PH}$, Rawlins JN: Spatial memory dissociations in mice lacking GluR1. Nat Neurosci 2002;5:868-873.

36 Choi DW: Glutamate neurotoxicity and diseases of the nervous system. Neuron 1998;1: 623-634.

37 Huang WT, Niu KC, Chang CK, Lin MT, Chang CP: Curcumin inhibits the increase of glutamate, hydroxyl radicals and PGE2 in the hypothalamus and reduces fever during LPS-induced systemic inflammation in rabbits. Eur J Pharmacol 2008;593:105-111.

38 Holcomb T, Taylor L, Trohkimoinen J, Curthoys NP: Isolation, characterization and expression of a human brain mitochondrial gluataminase cDNA. Brain Res Mol Brain Res 2000;76:56-63.

-39 Takeuchi H, Jin S, Wang J, Zhang G, Kawanokuchi J, Kuno R, Sonobe Y, Mizuno T, Suzumura A: Tumor necrosis factor-alpha induces neurotoxicity via glutamate release from hemichannels of activated microglia in an autocrine manner. J Biol Chem 2006;281: 21362-21368. 
-40 Yawata I, Takeuchi H, Doi Y, Liang J, Mizuno T, Suzumura A: Macrophage-induced neurotoxicity is mediated by glutamate and attenuated by glutaminase inhibitors and gap junction inhibitors. Life Sci 2008;82:11111116.

-41 Maezawa I, Jin LW: Rett syndrome microglia damage dendrites and synapses by the elevated release of glutamate. J Neurosci 2010: 30:5346-5356.

42 Tanaka K, Watase K, Manabe T, Yamada K, Watanabe M, Takahashi K, Iwama H, Nishikawa T, Ichihara N, Kikuchi T, Okuyama S, Kawashima N, Hori S, Takimoto M, Wada K: Epilepsy and exacerbation of brain injury in mice lacking the glutamate transporter GLT1. Science 1997;276:1699-1702.

43 Rothstein JD, Martin L, Levey AI, DykesHoberg M, Jin L, Wu D, Nash N, Kuncl RW: Localization of neuronal and glial glutamate transporters. Neuron 1994;13:713-725.

- 44 Lee HK, Takamiya K, Han JS, Man H, Kim $\mathrm{CH}$, Rumbaugh G, Yu S, Ding L, He C, Petralia RS, Wenthold RJ, Gallagher M, Hugarin RL: Phosphorylation of the AMPA receptor GluR1 is required for synaptic plasticity retention of spatial memory. Cell 2003;12:631643.

-45 Maldve RE, Zhang TA, Ferrani-Kile K, Schreiber SS, Lippmann MJ, Snyder GL, Fienberg AA, Leslie SW, Gonzales RA, Morrisett RA: DARPP-32 and regulation of the ethanol sensitivity of NMDA receptors in the nucleus accumbens. Nat Neurosci 2002;5: 641-648.

46 Mattson MP: Glutamate and neurotrophic factors in neuronal plasticity and disease. Ann NY Acad Sci 2008;1144:97-112.

- 47 Tao X, West AE, Chen WG, Corfas G, Greenberg ME: A calcium-responsive transcription factor, CaRF, that regulates neuronal activity-dependent expression of BDNF. Neuron 2002;33:383-395.

48 Saha RN, Liu X, Pahan K: Up-regulation of BDNF in astrocytes by TNF-alpha: a case for the neuroprotective role of cytokine. J Neuroimmune Pharmacol 2006;1:212-222.

$\checkmark 49$ Fontaine V, Mahand-Said S, Hanoteau N, Fuchs C, Pfizenmaier K, Eisel U: Neurodegenerative and neuroprotective effects of tumor necrosis factor (TNF) in retinal ischemia: opposite roles of TNF receptor 1 and TNF receptor 2. J Neurosci 2002;22:RC216.
50 Cheng B, Christakos S, Mattson MP: Tumor necrosis factors protect neurons against metabolic-excitotoxic insults and promote maintenance of calcium homeostasis. Neuron 1994;12:139-153.

-51 Yang F, Lindholm K, Konishi Y, Li R, Shen Y: Target depletion of distinct tumor necrosis factor receptor subtypes reveals hippocampal neuron death and survival through different signal transduction pathways. J Neurosci 2002;22:3025-3032.

52 Marchetti L, Schlett K, Pflzenmaier K, Eisel UL: Tumor necrosis factor (TNF)-mediated neuroprotection against glutamate-induced excitotoxicity is enhanced by N-methyl-Daspartate receptor activation. Essential role of a TNF receptor 2-mediated phosphatidylinositol 3-kinase-dependent NF-kappa B pathway. J Biol Chem 2004;279:3286932881.

53 Epstein J, Sanderson IR, MacDonald TT: Curcumin as a therapeutic agent: the evidence from in vitro, animal and human studies. Br J Nutr 2010;103:1545-1557.

54 Barrientos RM, Higgins EA, Biedenkapp JC, Sprunger DB, Wright-Hardesty KJ, Watkins LR, Rudy JW, Maier SF: Peripheral infection and aging interact to impair hippocampal memory consolidation. Neurobiol Aging 2006;27:723-732.

55 Rolls A, Shechter RR, London A, Zv Y, Ronen A, Levy R, Schwartz M: Toll-like receptors modulate adult hippocampal neurogenesis. Nat Cell Biol 2007;9:1081-1088.

56 Wadachi R, Hargreaves KM: Trigeminal nociceptors express TLR- 4 and CD14: a mechanism for pain due to infection. J Dent Res 2006;85:49-53.

57 Chakravarty S, Herkenham M: Toll-like receptor 4 on nonhematopoietic cells sustains CNS inflammation during endotoxemia, independent of systemic cytokines. J Neurosci 2005;25:1788-1796.

58 Chen X, Libang Y, He P, Li R: Differential activation of tumor necrosis factor receptors distinguishes between brains from Alzheimer's disease and non-demented patients. J Alzheimers Dis 2010;19:621-630.
59 He P, Zhong Z, Lindholm K, Berning L, Lee W, Lemere C, Staufenbiel M, Li R, Shen Y: Deletion of tumor necrosis factor death receptor inhibits amyloid beta generation and prevents learning and memory deficits in Alzheimer's mice. J Cell Biol 2007;178:829841.

60 Longhi L, Ortolano F, Zanier ER, Perego C, Sticchetti N, De Simoni MG: Effect of traumatic brain injury on cognitive function in mice lacking p 55 and p 75 tumor necrosis factor receptors. Acta Neurochir Suppl 2008; 102:409-413.

61 Simen BB, Duman CH, Simen AA, Duman RS: TNF alpha signaling in depression and anxiety: behavioral consequences of individual receptor targeting. Biol Psychiatry 2006; 59:775-785.

62 Stellwagen D, Malenka RC: Synaptic scaling mediated by glial TNF-alpha. Nature 2006; 440:1054-1059.

63 Turrigiano GG: The self-tuning of neuron: synaptic scaling of excitatory synapses. Cell 2008;135:422-435.

64 Beattie EC, Stellwagen D, Morishita W, Bresnahan JC, Ha BK, Von Zastrow M, Beattie MS, Malenka RC: Control of synaptic strength by glial TNF alpha. Science 2002; 295:2282-2285.

65 Tracey D, Klareskog L, Sasso EH, Salfeld JG, Tak PP: Tumor necrosis factor antagonistic mechanism of action: a comprehensive review. Pharmacol Ther 2008;117:244-279.

66 Grattendick KJ, Nakashima JM, Feng L, Giri SN, Margolin SB: Effects of three anti-TNFalpha drugs: etarnecept, infliximab and pirfenidone on release of TNF-alpha in medium and TNF-alpha associated with the cell in vitro. Int Immunopharmacol 2008;8:679-687.

67 Tobinik EL, Gross H: Rapid improvement in verbal fluency and aphasia following perispinal etarnecept in Alzheimer's disease. BMC Neurol 2008;8:27.

68 Chou RC, Kane MA, Gautam S, Ghirmire S: Tumor necrosis factor inhibition reduces the incidence of Alzheimer's disease in rheumatoid arthritis patients (abstract). ACR 2010; 640.

-69 Chandra V, Pandav R, Dodge HH, Johnston JM, Belle SH, DeKosky ST, Ganguli M: Incidence of Alzheimer's disease in a rural community in India: the Indo-US study. Neurology 2001;57:985-989. 